\title{
Comparative Efficacy of an Organic Acid Blend and Bacitracin Methylene Disalicylate as Growth Promoters in Broiler Chickens: Effects on Performance, Gut Histology, and Small Intestinal Milieu
}

\author{
Saikat Samanta, Sudipto Haldar, and Tapan Kumar Ghosh \\ Department of Animal Nutrition, Faculty of Veterinary \& Animal Sciences, West Bengal University of Animal \& Fishery Sciences, \\ 37 Kshudiram Bose Sarani, Kolkata, West Bengal 700037, India \\ Correspondence should be addressed to Sudipto Haldar, sudipto.haldar@gmail.com
}

Received 27 August 2009; Accepted 8 November 2009

Academic Editor: Kazim Sahin

Copyright ( 2010 Saikat Samanta et al. This is an open access article distributed under the Creative Commons Attribution License, which permits unrestricted use, distribution, and reproduction in any medium, provided the original work is properly cited.

\begin{abstract}
This study evaluated the efficacy of organic acids as a growth promoter for broiler chickens relative to antibiotic growth promoters (AGPs). Broiler chickens were supplemented with graded doses of an organic acid blend (OAB, $1 \mathrm{~g}$ and $2 \mathrm{~g} / \mathrm{kg}$ diet) and bacitracin methylene disalicylate (BMD, $0.5 \mathrm{~g}$ and $1 \mathrm{~g} / \mathrm{kg}$ diet) for 35 days. Supplementation of OAB improved $(P<.001)$ feed conversion ratio (FCR) and increased protein accretion $(P<.001)$. Dietary acidification caused $\mathrm{pH}$ of the gizzard to decline linearly $(P<.01)$ with the dose of supplemental OAB. In the lower intestine, $\mathrm{pH}$ remained unaffected by dietary treatments. Unlike BMD, supplemental $\mathrm{OAB}$ selectively promoted growth of lactobacilli in the small intestine. Moreover, compared to BMD, OAB tended to maintain the villi in the small intestine at a greater height. Although benefits of exceeding the dose of supplemental organic acids more than $1 \mathrm{~g} / \mathrm{kg}$ diet are not always conspicuous, based on the live weight and feed conversion data, supplementation of $2 \mathrm{~g}$ organic acid per $\mathrm{kg}$ diet may be recommended for total replacement of AGPs in broiler diet.
\end{abstract}

\section{Introduction}

The ban imposed on antibiotic growth promoters (AGPs) in livestock and poultry diets initiated a worldwide search for effective alternatives which would be equally efficacious and have no negative impact on animal welfare and consumer health. Performance of livestock and poultry is closely related to the qualitative and quantitative microbial loads in the alimentary tract of the host animal [1]. The bacterial population in the alimentary tract consists of both pathogenic and beneficial commensals and growth inhibition of the former would facilitate the population of the latter. Owing to the short life span in broilers, the later the beneficial microorganisms colonize in the intestinal tract, the more susceptible the birds become to infection caused by intestinal and environmental pathogens.

Organic acids such as citric, propionic, fumeric, and formic acids increased gastric proteolysis and improved digestibility of protein and amino acids. Additionally, these acids have been shown to inhibit the growth of intestinal bacteria which compete with the host animal for availability of nutrients and reduced toxic bacterial metabolites such as ammonia and amines. As a result, feed efficiency and growth performance of the host improved as it was reported in poultry $[2,3]$ and pigs [4]. However, in poultry, performance enhancement by dietary acidification is not as convincing as it is in pigs. Nevertheless, some workers reported encouraging results with fumaric, propionic, sorbic, and tartaric acids $[5,6]$ and dietary supplementation of formic or propionic acid was reported to reduce the number of enteric pathogens [7] and the incidence of Salmonella in carcass [8-10].

In this experiment, broiler chickens were supplemented with graded doses of an organic acid blend $(\mathrm{OAB})$ to evaluate the efficacy as a growth promoter compared to AGP and to study the effects of these two dietary supplements on gut morphology, alimentary tract $\mathrm{pH}$, and intestinal microbial counts. 


\section{Materials And Methods}

The experimental protocol was approved by the Institutional Animal Ethics Committee. A mixed flock of 200 one-dayold Kasila broiler chicks (developed by GPS Poultry, USA from Hubard parent line) was purchased from a local hatchery. Glucose and electrolyte solutions were offered to the birds upon arrival at the experimental room and ground corn was offered within 12 hours of hatching. Following weighing, 180 chicks were randomly assigned to 5 dietary treatments and 20 chicks were kept separately for a preexperimental slaughter. Each treatment group consisted of 6 replicates with 6 birds per replicate. The chicks in a replicate were placed in individual pens $(0.5 \mathrm{~m} \times 0.5 \mathrm{~m})$ on litter composed of fresh wood shavings. The pens were separated with plastic wire netting and contained plastic feeder and water troughs. Temperature inside the poultry house was maintained through heating elements fitted in the room at $35^{\circ} \mathrm{C}$ during the first 2 weeks, between 28 and $30^{\circ} \mathrm{C}$ during the subsequent couple of weeks and at about $25^{\circ} \mathrm{C}$ in the last week of the study. Continuous light was provided through compressed fluorescent lamps during the first 2 weeks of brooding. In the third week a dark period of one hour duration was introduced in the night and after 21 days the lights were turned off for 4 hours at night to reduce the activity of the birds. Exhaust fans were fitted in the experimental room to ensure adequate ventilation. The birds were vaccinated against New Castle disease (day 7 and 21 ) and infectious bursal disease (day 14). The starter (days 1-21) and the grower (days 22-35) diets (Table 1) fed to the birds were formulated to meet nutrient requirements [11]. The birds were fed ad libitum and a weighed quantity of feed was offered replicate-wise in equal proportions at $08: 00$ and $16: 00$ hours. The total duration of the experiment was 35 days.

The dietary treatments were comprised of feeding the birds with an unsupplemented basal diet (control), supplementation of the basal diet with either $1 \mathrm{~g}$ or $2 \mathrm{~g}$ of an organic acid blend $(\mathrm{OAB})$ per $\mathrm{kg}$ diet $(\mathrm{OAB} 1$ and $\mathrm{OAB} 2$, resp.) and either $0.5 \mathrm{~g}$ or $1 \mathrm{~g}$ bacitracin methylene disalicylate (BMD, containing $10 \%$ active BMD per $\mathrm{kg}$ diet (BMD 0.5 and $\mathrm{BMD} 1$ resp.). $\mathrm{OAB}$ contained orthophosphoric acid $(400 \mathrm{~g} / \mathrm{kg})$, formic acid $(150 \mathrm{~g} / \mathrm{kg})$, propionic acid and calcium propionate $(30 \mathrm{~g} / \mathrm{kg}$ resp.) in a powdered base (Acidbac $^{\mathrm{TM}}$, Dex ibèrica, Vila-Seca, Tarragona, Spain). The diets for the designated treatment groups were prepared in lots of $50 \mathrm{~kg}$, and the supplements (OAB and $\mathrm{BMD}$ ) were weighed and then mixed with $1 \mathrm{~kg}$ of respective diets in a small capacity mechanical blender. The mixture thus produced was then added to the remainder of the diet placed in a mechanical blender, and mixed for 30 minutes. The commercially applicable dose rates for both the organic acid blend and the antibiotic growth promoter were applied in this study.

Feed intake was recorded by replicate daily. The total body weight of a replicate was measured at the beginning and at the end of the study and the gain in body weight was calculated replicate-wise. Feed conversion ratio (FCR) was also calculated replicate-wise as a ratio between the total feed
TABLe 1: Composition of basal diet ( $\mathrm{g} / \mathrm{kg}$ unless stated otherwise).

\begin{tabular}{lcc}
\hline Ingredients & $\begin{array}{c}\text { Starter } \\
(\mathrm{d} 1-21)\end{array}$ & $\begin{array}{c}\text { Finisher } \\
(\mathrm{d} 22-35)\end{array}$ \\
\hline Ground maize & 545 & 610 \\
Soybean oil & - & 7 \\
De-oiled rice bran & 35 & 46.8 \\
Soybean meal (44\% CP) & 386 & 304 \\
Oyster shell grit & 18 & 17 \\
Di-calcium phosphate & 10 & 9 \\
Common salt & 1 & 1 \\
Methionine & 1.8 & 1.8 \\
Lysine & 0.5 & 0.7 \\
NSP enzyme & 0.5 & 0.5 \\
Phytase & 0.2 & 0.2 \\
Vitamin and trace mineral premix & 2 & 2 \\
Nutrient value (calculated value) & & \\
Metabolizable energy MJ/kg & 11.7 & 12.2 \\
Crude protein & 229 & 197 \\
Calcium & 9.5 & 8.7 \\
Phosphorus & 3.5 & 3.2 \\
Lysine & 3.4 & 4.15 \\
Methionine & 5.5 & 5.7 \\
\hline
\end{tabular}

${ }^{\dagger}$ Contained (per kg) retinyl acetate $(3.75 \mathrm{mg}), 1,25$-hydroxycholecalciferol $4 \mathrm{mg}$, DL $\alpha$-tocopheryl acetate $30 \mathrm{mg}$, menadione $4 \mathrm{mg}$, thiamine disulfide $3 \mathrm{mg}$, riboflavin tetrabutyrate $8 \mathrm{mg}$, methylcobalamine $0.025 \mathrm{mg}$, sodium pantothenate $15 \mathrm{mg}$, pyridoxine $5 \mathrm{mg}$, niacin $60 \mathrm{mg}$, biotin $0.2 \mathrm{mg}$, folic acid $2 \mathrm{mg}$ and manganese $90 \mathrm{~g}$, zinc $80 \mathrm{~g}$, iron $90 \mathrm{~g}$, copper $15 \mathrm{~g}$ (all as sulfate salt), iodine (as potassium iodide) $2 \mathrm{~g}$, selenium (as sodium selenite) $0.3 \mathrm{~g}$.

intake by a replicate and the total body weight gain of that replicate. Mortality, if any, was recorded and the data were adjusted accordingly.

As stated above an initial slaughter of 20 chicks was performed on day 0 to determine some pre-experimental carcass traits to be described later and the birds were harvested finally on day 35 by decapitation. The slaughter was performed 2 hours after feeding. The birds were defeathered and eviscerated manually. The feet and heads were removed and the carcass was split longitudinally. The hot carcass was weighted and chilled at $1^{\circ} \mathrm{C}$ for 48 hours. The chilled carcass was separated into cuts, and the breast, thighs, back, drumsticks, and giblets (gizzard, liver, lungs and heart) were weighed. The cuts were frozen at $-20^{\circ} \mathrm{C}$ for analysis. The frozen cuts from the left side of each carcass were homogenized in a custom made tissue homogenizer. The minced subsamples were repeatedly taken and mixed until a final sample of $500 \mathrm{~g}$ was obtained. The final sample was frozen pending analysis of moisture, ash (AOAC 1984), and crude protein $(\mathrm{N} \times 6.25)$. $\mathrm{N}$ was analyzed in an automatic analyzer (Kjeltec Auto 1013 Analyzer, Foss Tecator, Sweden). The samples from the initial slaughter group were also analyzed similarly. Protein and ash accretion was determined by subtracting the total quantity of the a forementioned nutrients in carcass on $\mathrm{d} 35$ from those in the initial slaughter group. 
Following sacrificing of the birds on d 35 for carcass traits, the intact gastrointestinal tract from the esophagus to the cecum was separated and placed in sterile Petri dishes after washing with normal saline to remove exterior blood and tissue debris. The gastrointestinal tract from 2 birds in a replicate of a treatment group was cut into segments and the digesta from the crop, proventriculus, gizzard, duodenum and ileum were gently expelled into plastic containers and pooled by replicate. The $\mathrm{pH}$ of the pooled sample was determined (Digital $\mathrm{pH}$ meter, Model 335 , Systronics, Thiland) following dilution to $10 \mathrm{ml}$ with deionized water. The small intestine (from the end point of the gizzard up to the ileo-caecal junction) was dissected from 2 birds of a replicate in each treatment group and the duodenum, jejunum, and ileum were separated. The digesta were taken from each segment in sterile Petri dishes and pooled by replicate. One gram of the pooled digesta was taken segment wise in sterile test tubes and diluted to $10 \mathrm{ml}$ with sterilized deionized water. The contents were then serially diluted and a final dilution of $10^{-5}$ was used for enumeration of Escherichia coli, Clostridium, Salmonella total coliforms and Lactobacillus spp. For this, $0.1 \mathrm{ml}$ diluted digesta was spread with a sterile platinum loop on the surface of bacteria specific culture media (Hi Touch Flexi Plates, Hi Media Laboratories Ltd., Mumbai, India) and incubated at $37^{\circ} \mathrm{C}$ for 24 to 48 hours. The colonies were enumerated using a colony counter (manufactured by Optics Technilogy, New Delhi, India) the and the results were expressed as $\log _{10}$ Colony Forming Units (CFU)/g digesta.

The starter and the finisher feeds were also analyzed in a similar way for total coliforms, E. coli, Clostridium, Salmonella, and moulds (Aspergillus flavus and A. parasiticus). For this, $1 \mathrm{~g}$ of finely ground feed sample was mixed with sterilized deionized water and cultures were grown on specific culture media mentioned above following serial dilution. Growth of the microorganisms and the molds was tested after 24 to 48 hours and the colonies were enumerated.

The duodenum, jejunum, and ileum obtained from each of the birds in a replicate of a treatment group were processed further for estimation of villus height. The segments were cut into small pieces not exceeding $2 \mathrm{~mm}$ in length and immersed into alcoholic Bouin's fluid (containing $150 \mathrm{ml}$ $80 \%$ ethyl alcohol, $1 \mathrm{~g}$ picric acid, and $60 \mathrm{ml}$ formaldehyde with $50 \mathrm{ml}$ glacial acetic acid added immediately before use) for a period of 16 hours. The fixative was then poured off and the tissue was washed thoroughly with $70 \%$ alcohol and dehydrated in ascending grades (80\%, 90\%, and absolute) of alcohol. The tissue segments were then immersed in a solution containing alcohol and cedar wood oil (1:1 volume/volume) for 16 hours and then kept in cedar wood oil for 48 hours. The tissue segments were then transferred to a solution containing xylene and paraffin wax at a ratio of $1: 1$ and kept in an incubator at 56 to $58^{\circ} \mathrm{C}$ for 2 hours with a change in paraffin solution after 1 hour. A quantity of molten paraffin was poured into a small paper block into which the tissue was then transferred and the paraffin was allowed to harden and cut into suitable blocks from which tissue sections were cut at $6 \mu \mathrm{m}$ with the help of a microtome. The sections were placed on glass slides and kept on a hot plate to get the sections adhered on the slides. The slides were then stained with Delafield's Hematoxyline and Eosin and mounted on Distrene Plasticiser Xylene. The length of the villi was measured with an oculometer under a microscope fitted with a stage micrometer. For each specimen, at least 10 fields were scanned and the mean value for the 10 observations was considered to be a measurable unit for each specimen during subsequent calculations.

The data were analyzed by the general linear model of the SPSS (10.0) and the results were expressed as mean and pooled standard error of mean (SE). The replicates were the experimental units. The control group was used as a common control for both the $\mathrm{OAB}$ and the BMD dietary groups. The results were subjected to ANOVA to compare the mean effects of dietary treatments $(\mathrm{OAB}$ and BMD) irrespective of the dose levels. Separate analysis was performed employing polynomial contrast to determine the effects of varying dose levels within a dietary treatment. A probability less than 0.05 was considered significant and less than 0.1 was considered trend.

\section{Results}

There was no difference in chemical analysis results between the starter and finisher diets (Table 2). Total coliforms in the starter and the finisher diets decreased $(P<.05)$ due to supplementation of $\mathrm{OAB}$ and $\mathrm{BMD}$ and the difference between the dietary treatments was not significant in this regard $(P>.1)$. E. coli and Clostridium in both the starter and the finisher diets decreased linearly $(P<.05)$ with the dose of the supplemental OAB. When BMD was supplemented, E. coli decreased $(P<.05)$ compared to the control diet, although in the starter feed the dose of BMD had little effect on dietary E. coli count $(P>.1)$. However, E. coli in the finisher diet and clostridia in both the starter and finisher diets decreased linearly $(P<.05)$ with the dose of the supplemental BMD in diet. Salmonella test was negative for all the three dietary groups. The growth of A. flavus and A. parasiticus was either detected sporadically or was not detected at all in most of the cultures. Some mucoid growths were observed in the OAB supplemented diets. Growth of $A$. flavus was higher in the BMD 0.5 than other diets $(P<.05)$. A. fumigatus was, however, negative in both the $\mathrm{OAB}$ and BMD supplemented diets (Table 2).

Data related to live weight, live weight gain, FCR, gross carcass traits, and chemical composition of meat (Table 3 ) indicated that live weight increased linearly $(P<.01)$ due to supplementation of either $\mathrm{OAB}$ or BMD to the diets. Consequently, live weight gain improved in the a forementioned treatment groups $(P<.01)$. Cumulative FCR was better $(P<.001)$ in the birds supplemented with $\mathrm{OAB}$ than those supplemented with the BMD. Among the OAB dietary groups, FCR was better $(P<.001$, linear and quadratic effects) in the $\mathrm{OAB} 1$ group compared to that in the OAB 2 group of birds. Similarly, the BMD 0.5 dietary group had a better FCR than the BMD 1 group of birds $(P<.05$, linear and quadratic effects). No mortality was recorded during the study. 
TABLE 2: Chemical composition (g/kg) and microbiological count $\left(\log _{10}\right.$ CFU/g) of the experimental diets supplemented with an organic acid blend $(\mathrm{OAB})$ and bacitracin methylene disalicylate (BMD).

\begin{tabular}{|c|c|c|c|c|c|c|c|c|c|}
\hline \multirow[b]{3}{*}{ Chemical compositin } & \multirow[t]{3}{*}{ Diet } & \multicolumn{5}{|c|}{ Dietary treatments } & \multicolumn{3}{|c|}{ Significance $(P$ value $)$} \\
\hline & & \multirow[t]{2}{*}{ Control } & \multicolumn{2}{|c|}{$\mathrm{OAB}$} & \multicolumn{2}{|c|}{$\mathrm{BMD}$} & \multicolumn{2}{|c|}{ Dose effect } & \multirow{2}{*}{ Between treatments } \\
\hline & & & $1 \mathrm{~g} / \mathrm{kg}$ diet & $2 \mathrm{~g} / \mathrm{kg}$ diet & $0.5 \mathrm{~g} / \mathrm{kg}$ diet & $1.0 \mathrm{~g} / \mathrm{kg}$ diet & $\mathrm{OAB}$ & BMD & \\
\hline \multirow[t]{2}{*}{ Crude protein* } & Starter & 226.6 & 228.7 & 230.1 & 229.2 & 228.7 & NS & NS & NS \\
\hline & Finisher & 197.1 & 197.7 & 197.3 & 198.2 & 198.8 & NS & NS & NS \\
\hline \multirow[t]{2}{*}{ Crud fiber } & Starter & 43.9 & 42.5 & 42.9 & 43.2 & 43.8 & NS & NS & NS \\
\hline & Finisher & 37.6 & 35.4 & 35.9 & 36.8 & 37.2 & NS & NS & NS \\
\hline \multirow[t]{2}{*}{ Ether extract } & Starter & 29.5 & 29.3 & 29.1 & 29.2 & 9.3 & NS & NS & NS \\
\hline & Finisher & 38.7 & 38.8 & 38.6 & 38.5 & 8.7 & NS & NS & NS \\
\hline \multicolumn{10}{|l|}{ Microbial counts ${ }^{\dagger}$} \\
\hline \multirow[t]{2}{*}{ Total coliforms } & Starter & 18 & 16 & 14 & 13 & 15 & $*$ & $*$ & NS \\
\hline & Finisher & 19 & 12 & 14 & 16 & 11 & * & * & NS \\
\hline \multirow[t]{2}{*}{ Escherichia coli } & Starter & 4 & 2 & - & 2 & 2 & * & NS & * \\
\hline & Finisher & 4 & 3 & - & 2 & 1 & * & * & NS \\
\hline \multirow[t]{2}{*}{ Clostridium spp. } & Starter & 210 & 180 & 170 & 200 & 180 & $*$ & $*$ & * \\
\hline & Finisher & 200 & 180 & 160 & 180 & 160 & $*$ & $*$ & * \\
\hline \multirow[t]{2}{*}{ Aspergillus flavus $\$$} & Starter & - & — $^{\ddagger}$ & 2 & 1 & - & & & \\
\hline & Finisher & 1 & $-^{\ddagger}$ & - & 3 & - & & & \\
\hline \multirow[t]{2}{*}{ Aspergillus fumigatus $\$$} & Starter & 2 & - & $-^{\ddagger}$ & - & - & & & \\
\hline & Finisher & 2 & - & - & - & - & & & \\
\hline
\end{tabular}

$\$$ Statistical analysis not performed due to lack of sufficient data; ${ }^{\dagger}$ Salmonella was negative for all the diets; ${ }^{\ddagger}$ mucoid growths were observed.

* Significance at $P<.05$; NS, not significant.

TABLE 3: Effects of feeding an organic acid blend (OAB) and bacitracin methylene disalicylate (BMD) at different dose levels on performance traits and carcass characteristics in broiler chicken ${ }^{\dagger}$.

\begin{tabular}{|c|c|c|c|c|c|c|c|c|c|}
\hline \multirow{3}{*}{ Measurements } & \multirow{3}{*}{ Control (Basal diet) } & \multicolumn{3}{|c|}{ Dietary treatments } & & \multirow[t]{3}{*}{ Pooled SE } & \multicolumn{3}{|c|}{ Contrast $P$ value } \\
\hline & & \multirow{2}{*}{\multicolumn{4}{|c|}{$\begin{array}{cc}\text { OAB } & \text { BMD } \\
1 \mathrm{~g} / \mathrm{kg} \text { diet } 2 \mathrm{~g} / \mathrm{kg} \text { diet } 0.5 \mathrm{~g} / \mathrm{kg} \text { diet } 1.0 \mathrm{~g} / \mathrm{kg} \text { diet }\end{array}$}} & & \multicolumn{2}{|c|}{ Dose effect } & \multirow{2}{*}{ Between treatments } \\
\hline & & & & & & & $\mathrm{OA}$ & BMD & \\
\hline \multicolumn{10}{|c|}{ Live performance and gross carcass traits } \\
\hline Final live weight g & 1510 & 1686 & 1773 & 1740 & 1717 & 13.2 & $* * * \mathrm{~L}$ & $* * \mathrm{LQ}$ & $* * *$ \\
\hline Total gain g & 1471 & 1648 & 1735 & 1702 & 1678 & 13.1 & $* * * \mathrm{~L}$ & ** LQ & $* * *$ \\
\hline Overall FCR ${ }^{\ddagger}$ & 2.03 & 1.69 & 1.73 & 1.79 & 1.85 & 0.02 & ***LQ & $* * \mathrm{LQ}$ & $* * *$ \\
\hline Dressing percentage & 56.9 & 58.7 & 57.9 & 57.1 & 59.6 & 0.26 & NS & $* * \mathrm{~L}$ & $*$ \\
\hline Breast g & 220 & 290 & 261 & 283 & 310 & 9.3 & ${ }^{*} \mathrm{~L}$ & ${ }^{*} \mathrm{~L}$ & NS \\
\hline Thigh g & 123 & 152 & 144 & 153 & 167 & 3.9 & $\$$ & ${ }^{*} \mathrm{~L}$ & NS \\
\hline Drumstick g & 125 & 151 & 146 & 166 & 187 & 4.4 & NS & $* * \mathrm{~L}$ & $*$ \\
\hline \multicolumn{10}{|c|}{ Chemical composition ( $\mathrm{g} / 100 \mathrm{~g}$ meat on fresh basis) and nutrient accretion (g) } \\
\hline Moisture & 72.2 & 73.9 & 73.8 & 73.6 & 72.8 & 0.31 & NS & NS & NS \\
\hline Ash & 3.59 & 6.89 & 5.41 & 3.66 & 3.92 & 0.15 & $* * \mathrm{LQ}$ & NS & ** \\
\hline Protein & 21.9 & 22.1 & 22.1 & 20.4 & 21.8 & 0.21 & NS & $\$$ & NS \\
\hline Protein accretion & 321.8 & 384.9 & 383.9 & 347.6 & 366.4 & 4.37 & $* * \mathrm{~L}$ & $\$$ & $* * *$ \\
\hline Ash accretion & 50.2 & 113.4 & 92.5 & 60.2 & 63.7 & 2.54 & ${ }^{* *} \mathrm{LQ}$ & NS & $* * *$ \\
\hline
\end{tabular}

${ }^{\dagger}$ The birds were on test for 35 days, ${ }^{\ddagger}$ Feed conversion ratio, calculated by dividing total feed intake by total live weight gain in 35 days. ${ }^{L}$ significant linear

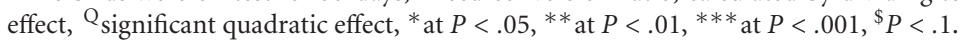


TABLE 4: Effect of feeding organic acid blend (OA) and bacitracin methylene disalicylate (BMD) at different dose levels on pH of different segments of the gastrointestinal tract, microbial counts in the digesta contents of the small intestine and length of the villi in different segments of the small intestine ${ }^{\dagger}$.

\begin{tabular}{|c|c|c|c|c|c|c|c|c|c|}
\hline \multirow{3}{*}{ Measurements } & \multirow{3}{*}{ Control (Basal diet) } & \multicolumn{3}{|c|}{ Dietary treatments } & & \multirow[t]{3}{*}{ Pooled SE } & \multicolumn{3}{|c|}{ Contrast $P$ value } \\
\hline & & & $\mathrm{AB}$ & & & & \multicolumn{2}{|c|}{ Dose effect } & \multirow{2}{*}{ Between treatments } \\
\hline & & \multicolumn{4}{|c|}{$1 \mathrm{~g} / \mathrm{kg}$ diet $2 \mathrm{~g} / \mathrm{kg}$ diet $0.5 \mathrm{~g} / \mathrm{kg}$ diet $1.0 \mathrm{~g} / \mathrm{kg}$ diet } & & OA & $\mathrm{BMD}$ & \\
\hline \multicolumn{10}{|c|}{$\mathrm{pH}$ in different segments of the gastrointestinal tract } \\
\hline Crop & 4.75 & 4.90 & 4.71 & 4.78 & 5.32 & 0.069 & NS & NS & NS \\
\hline Proventriculus & 3.03 & 2.95 & 3.07 & 3.13 & 2.4 & 0.089 & NS & $\$$ & NS \\
\hline Gizzard & 3.23 & 2.63 & 2.61 & 3.15 & 2.52 & 0.059 & $* * \mathrm{LQ}$ & $* * \mathrm{~L}$ & NS \\
\hline Duodenum & 6.18 & 6.12 & 6.27 & 5.98 & 6.38 & 0.06 & NS & NS & NS \\
\hline Jejunum & 6.32 & 6.29 & 6.28 & 6.35 & 6.34 & .09 & NS & NS & NS \\
\hline Ileum & 6.97 & 7.17 & 7.18 & 7.4 & 7.28 & 0.055 & NS & $\$$ & NS \\
\hline \multicolumn{10}{|c|}{ Microbial counts of the digesta in different segments of the small intestine ( $\log _{10}$ CFU/g digesta) } \\
\hline Escherichia coli & 3.78 & 3.38 & 3.7 & 2.22 & 1.27 & 0.582 & NS & NS & NS \\
\hline Other coliforms & 2.72 & 2.6 & 2.63 & 2.65 & 0.63 & 0.422 & NS & NS & NS \\
\hline Lactobacillus spp. & 2.43 & 6.5 & 1.5 & 1.5 & 1.2 & 0.32 & ${ }^{* *} \mathrm{Q}$ & NS & $*$ \\
\hline \multicolumn{10}{|c|}{ Height of villi $(\mu \mathrm{m})$ in different segments of small intestine } \\
\hline Duodenum & 1513 & 1524 & 1667 & 1197 & 1238 & 25.74 & ${ }^{*} \mathrm{~L}$ & **LQ & $* * *$ \\
\hline Jejunum & 996 & 1049 & 1063 & 984 & 1287 & 16.37 & $* \mathrm{Q}$ & $* * *$ LQ & $*$ \\
\hline Ileum & 799 & 752 & 822 & 697 & 747 & 7.46 & *LQ & $* * *$ LQ & * \\
\hline
\end{tabular}

${ }^{\dagger}$ Birds were harvested on d 35, ${ }^{\mathrm{L}}$ significant linear effect, ${ }^{\mathrm{Q}}$ significant quadratic effect, ${ }^{*}$ at $P<.05,{ }^{* *}$ at $P<.01,{ }^{*}$ at ${ }^{\$} P<.001, P<.1$.

Tests for Salmonella and Clostridium were negative and hence the results are not shown.

The dose levels of supplemental OAB had no effect on the dressing percentage $(P>.1)$. However, dressing percentage improved linearly $(P<.01)$ with the dose of supplemental $\mathrm{BMD}$. Irrespective of dose, dressing percentage of the $\mathrm{OAB}$ and BMD supplemented dietary groups was similar $(P>.1)$. Breast weight increased linearly $(P<.05)$ with the dose of $\mathrm{OAB}$ and BMD in diet. Dietary supplemental OAB tended to increase thigh weight $(P<.1)$. Contrarily, added BMD in diet resulted in a linear increase in weight of the thighs $(P<.05)$. Cumulatively, the difference between the OAB and $\mathrm{BMD}$ supplemented dietary groups was not significant with regard to the weight of the breast and thighs $(P>$ .1). Supplemental OAB had little impact on weight of the drumsticks $(P>.1)$. On the other hand, when BMD was supplemented to the diet, the weight of the drumstick increased with the dose $(P<.001$, linear effect).

Moisture in meat ranged from $72.2 \%$ to $73.9 \%$ in different experimental groups and the dietary treatments had little effect on meat moisture content $(P>.1)$. Irrespective of dose, supplementation of $\mathrm{OAB}$ increased meat ash content and total ash accretion more than BMD did $(P<.001)$. In the $\mathrm{OAB} 1$ dietary group meat ash content was higher $(P<.001$, linear and quadratic effects $)$ than the control and $\mathrm{OAB} 2$ dietary groups. Supplemental BMD, however, had little effect on meat ash content with little variation being observed between the BMD 0.5 and BMD 1 dietary groups. Supplementation of OAB and BMD did not affect meat protein content $(P>.1)$. Meat protein tended to increase $(P<.1)$ with the dose of supplemental BMD, although any dose dependent effect with $\mathrm{OAB}$ was lacking in this regard. However, protein accretion increased linearly as the dose of supplemental OAB $(P<.001)$ or BMD $(P<$ .05 ) increased in diet. Irrespective of the dose levels, protein accretion in the $\mathrm{OAB}$ supplemented group of birds was higher than that in the BMD supplemented dietary groups $(P<.001)$.

Supplemental OAB and BMD had little effect on $\mathrm{pH}$ of the crop $(P>.1)$. The $\mathrm{pH}$ of the proventriculus also did not reveal marked change when $\mathrm{OAB}$ was supplemented to the $\operatorname{diet}(P>.1)$, although the same tended to decrease with the dose of supplemental BMD in diet $(P<.1)$. On the other hand, dietary acidification caused the $\mathrm{pH}$ of the gizzard to decline linearly $(P<.01)$ with the dose of supplemental OAB. However, supplementation of BMD did not yield any significant effect $(P>.1)$ on the $\mathrm{pH}$ of the gizzard. Dietary supplementation of $\mathrm{OAB}$ or BMD did not affect $\mathrm{pH}$ of the duodenum $(P>.1)$. In the ileum also the $\mathrm{pH}$ remained unaffected by supplementation of $\mathrm{OAB}(P>.1)$, although in the ileum it tended to be higher $(P<.1)$ in the BMD 0.5 group compared to that in the BMD 1 dietary group (Table 4).

The population of E. coli, Lactobacillus, and other coliforms in the digesta content of the small intestine is presented in Table 4. Dietary supplemental OAB and BMD did not affect $E$. coli in the small intestine $(P>.1)$. Other coliform counts were similar in the $\mathrm{OAB}$ and the BMD supplemented dietary groups $(P>.1)$. Lactobacillus was quadratically higher in the $\mathrm{OAB} 1$ group than the control and the OAB 2 dietary groups $(P<.001)$. Addition of BMD in diet had no effect on gut Lactobacillus population $(P>.1)$. Overall, supplementation of $1 \mathrm{~g} \mathrm{OAB} / \mathrm{kg}$ diet was found to be superior $(P<.01)$ in terms of intestinal Lactobacillus count 
to the control and other experimental groups. Salmonella and Clostridium tests were negative across the dietary treatments.

Supplementation of OAB and BMD had variable effect on the villus height in different segments of the small intestine (Table 4). The general trend indicated that supplementation of organic acids facilitated the growth of the villi compared to the BMD. In the duodenum, villus height increased linearly with the dose of the organic acids $(P<.05)$ and the trend was similar in the jejunum $(P<.05$, quadratic effects) and the ileum as well $(P<.05$, linear and quadratic effects). The height of villi in the BMD supplemented dietary group also increased linearly in a dose dependent manner $(P<.01$, linear and quadratic effects). Interestingly, the height of the ileal villi in the OAB 1, BMD 0.5, and BMD 1 dietary groups was lower $(P<.05)$ relative to the control group of birds.

\section{Discussion}

Dietary supplementation of organic acid reduced E. coli and Clostridium more efficiently than BMD. The effect of organic acid in reducing total coliforms was comparable to BMD. It may be noted that despite the dietary samples being positive in Salmonella and Clostridium the same could not be detected in the alimentary tract of the birds. Perhaps the dietary load of these bacteria was not sufficient enough to induce a clinical infection and the organisms failed to establish themselves in the gut due to competitive antagonism from other commensals present in the gut. The effects of organic acids and BMD on the growth of Aspergillus spp. were somewhat inconsistent. Nevertheless, it appeared that addition of organic acids and BMD resulted in complete disappearance of Aspergillus fumigatus in the feed samples.

In the present investigation, the organic acids were found to be superior to BMD in enhancing live performance of the experimental birds probably by their beneficial effects on gut micro flora. Øverland et al. [12] reported that organic acids such as formic acid, elicit bactericidal effects by reducing the intracellular $\mathrm{pH}$ of gut micro flora which in turn may improve livestock performance. It is worth mentioning here that Lactobacillus is capable of growing at a relatively lower $\mathrm{pH}$ and thus is more resistant to changes in gut milieu induced by dietary acidification [13]. In poultry, pathogenic bacteria like Salmonella enter the gastrointestinal tract via the crop. The microbial composition and $\mathrm{pH}$ of the crop influenced the establishment of pathogens over there and a relatively higher Lactobacillus count along with a lower $\mathrm{pH}$ could decrease the occurrence of Salmonella in the crop [14]. It has been reported that the antimicrobial activity of organic acids is restricted within the crop and gizzard and any drastic changes of $\mathrm{pH}$ distally in the small intestine due to supplementation of organic acid are unlikely [3]. During the present investigation also supplementation of $\mathrm{OAB}$ decreased $\mathrm{pH}$ of only the gizzard, which corroborated the above hypothesis. It is intriguing to note that irrespective of dietary treatments $\mathrm{pH}$ in the gizzard was lower than that in the proventriculus, although the difference was not significant statistically. It may be mentioned that the $\mathrm{pH}$ mentioned in this article refers to that of the gut contents and not the $\mathrm{pH}$ of gut segments per se. The birds were slaughtered 2 hours postprandial and it is possible that post feeding acid production in the proventriculus passed off the peak level and the contents present there came down to the gizzard by the time the contents were collected. As a consequence, the contents present in the gizzard might show a comparatively lower $\mathrm{pH}$ than those of the proventriculus. Further, although there was little change in the population of E. coli and other coliforms, the lactobacilli increased in the OAB 1 dietary group. This was indicative of an antimicrobial action of the $\mathrm{OAB}$ at the upper alimentary tract. As it was discussed above, the antimicrobial action of $\mathrm{OAB}$ in the gizzard might have had reduced the number of the Enterobacterioceae and increased that of the Lactobacillus in the small intestine as a compensatory mechanism. Øverland et al. [12] reported that in growing-finishing pigs, population of the coliforms in the duodenum, jejunum, and ileum decreased when 1.2\% potassium diformate was added to the diet. Gedek et al. [15] also reported that addition of $1.8 \%$ formic acid in diet reduced $E$. coli in the cecum and faeces. The coliforms in the present study can be assumed to be the representative for most of the enteric forms such as the Salmonella, Shigella and Enterobacter [16] and their reduction along with the E. coli wich ought to be beneficial for the host [12]. Because the microbial population is reduced, the metabolic needs are also reduced thereby increasing the availability of nutrients to the host. Supplemental OAB facilitated this process and thus augmented the performance of the experimental birds. On the other hand, a lower population of the enteric bacteria including the Lactobacillus in the BMD supplemented groups corroborated the earlier findings [17-19]. Decuypere et al. [20] reported that AGPs such as zinc bacitracin and virginiamycin may decrease the Lactobacillus and increase the coliforms in the alimentary tract of young pigs. In the present investigation also, the reduction in the number of Lactobacillus relative to that of the E. coli and the other coliforms was more in the BMD supplemented birds.

Apart from $\mathrm{pH}$ and microbiological profile of the gut, histology of the small intestine might influence the performance of the birds in this study. Nutrient absorption in gut occurs from the intestinal mucosa and hence, manipulation thereon may improve the nutrient utilization in vivo [21-23]. In this study supplemental OAB increased the height of villi which probably facilitated nutrient absorption to a greater extent than that occurred in the BMD supplemented dietary group. Supplementation of probiotics in gut reportedly augmented growth and stability of specific bacteria which produce organic acids and this, in turn, might increase the height of the villi $[22,24]$. It may be mentioned that the villus height in the BMD 1 group of birds was higher than the rest of the treatment groups in the jejunum where maximum digestion and absorption takes place because of a large luminal site and presence of more mature enterocytes [25]. This is quite intriguing since the performance of this particular group was comparatively inferior across the dietary treatments. However, it is worth mentioning that the villi in the jejunum of the birds receiving $\mathrm{OAB}$ as the dietary supplement were arranged in a zigzag fashion 
resembling a wave. According to Yamauchi and Isshiki [26], nutrient absorption occurs more efficiently when the villi are arranged in the aforementioned pattern than when they are positioned parallel. A wave like disposition of the villi would facilitate a better contact between the nutrients and the absorptive surface of the intestinal epithelium because the passage of feed through the alimentary canal becomes more time consuming through the zigzag flask than that occurring through a straight flask. This invariably results in a better nutrient utilization. The higher villus height coupled with a higher Lactobacillus count plausibly caused a better body weight and FCR in the OAB dietary groups.

It was concluded that dietary supplementation of organic acids may effectively replace AGPs as a growth promoter in broiler diets. Organic acids may yield superior effects in terms of growth performance compared to the AGPs such as BMD. The effects of organic acids may be related to a reduction in $\mathrm{pH}$ in gizzard and selective promotion of beneficial bacteria like Lactobacillus in the gut. Maintenance of villi in the small intestine at a greater height may be the other reason which makes the organic acids superior to the AGPs. Although, benefits of exceeding the dose of supplemental organic acids more than $1 \mathrm{~g} / \mathrm{kg}$ diet are not always conspicuous, based on the live weight and feed conversion data, supplementation of $2 \mathrm{~g}$ organic acid per $\mathrm{kg}$ diet may be recommended for total replacement of AGPs in broiler diet.

\section{References}

[1] M. N. Garrido, M. Skjervheim, H. Oppegaard, and H. Sørum, "Acidified litter benefits the intestinal flora balance of broiler chickens," Applied and Environmental Microbiology, vol. 70, no. 9, pp. 5208-5213, 2004.

[2] M. Hinton and A. H. Linton, "Control of Salmonella infections in broiler chickens by the acid treatment of their feed," Veterinary Record, vol. 123, no. 16, pp. 416-421, 1988.

[3] J. L. Thompson and M. Hinton, "Antibacterial activity of formic and propionic acids in the diet of hens on Salmonellas in the crop," British Poultry Science, vol. 38, no. 1, pp. 59-65, 1997.

[4] K. H. Partanen and Z. Mroz, "Organic acids for performance enhancement in pig diets," Nutrition Research Reviews, vol. 12, no. 1, pp. 117-145, 1999.

[5] H. Vogt, S. Matthes, and S. Harnisch, "Der Einfluss organischer Säuren auf die Leistungen von Broilern und Legehennen," Archiv für Geflügelkunde, vol. 45, pp. 221-232, 1981.

[6] H. Vogt, S. Matthes, and S. Harnisch, "Der Einfluss organischer Säuren auf die Leistungen von Broilern. 2. Mittelung," Archiv für Geflügelkunde, vol. 46, pp. 223-227, 1982.

[7] M. Alp, N. Kocabağli, R. Kahraman, and K. Bostan, "Effects of dietary supplementation with organic and zinc bacitracin on ileal microflora, $\mathrm{pH}$ and performance in broilers," Turkish Journal of Veterinary and Animal Sciences, vol. 23, no. 5, pp. 451-455, 1999.

[8] M. Hinton, A. H. Linton, and F. G. Perry, "Control of Salmonella by acid disinfection of chicks' food," Veterinary Record, vol. 116, no. 18, p. 502, 1985.

[9] A. L. Izat, M. Colberg, M. H. Adam, M. A. Reibar, and P. W. Waldroup, "Production and processing studies to reduce the incidence of Salmonella on commercial broilers," Journal of Food Protection, vol. 52, pp. 670-673, 1989.

[10] J. Rouse, A. Rolow, and C. E. Nelson, "Effect of chemical treatment of poultry feed on survival of Salmonella," Poultry Science, vol. 67, no. 8, pp. 1225-1228, 1988.

[11] National Research Council, Nutrient Requirements of Poultry, National Academy Press, Washington, DC, USA, 1994.

[12] M. Øverland, T. Granli, N. P. Kjos, O. Fjetland, S. H. Steien, and M. Stokstad, "Effect of dietary formates on growth performance, carcass traits, sensory quality, intestinal microflora, and stomach alterations in growing-finishing pigs," Journal of Animal Science, vol. 78, no. 7, pp. 1875-1884, 2000.

[13] J. B. Russe 11 and F. Diez-Gonzalez, "The effects of fermentation acids on bacterial growth," Advances in Microbial Physiology, vol. 39, pp. 205-234, 1998.

[14] A. Hinton Jr., R. J. Buhr, and K. D. Ingram, "Reduction of Salmonella in the crop of broiler chickens subjected to feed withdrawal," Poultry Science, vol. 79, no. 11, pp. 1566-1570, 2000.

[15] B. Gedek, F. X. Roth, M. Kirchgessner, S. Wiehler, A. Bott, and U. Eidelsburger, "Influence of fumaric acid, hydrochloric acid, sodium fumarate, Tylosin and Toyocerine on the microflora in different segments of gastrointestinal tract. 14. Communication. Investigations about the nutritive efficiency of organic acids in the rearing of piglets," Journal of Animal Physiology and Animal Nutrition, vol. 68, pp. 209-217, 1992.

[16] C. E. Östling and S. E. Lindgren, "Inhibition of enterobacteria and Listeria growth by lactic, acetic and formic acids," Journal of Applied Bacteriology, vol. 75, no. 1, pp. 18-24, 1993.

[17] M. Alp, N. Kocabagli, R. Kahraman, and K. Bostan, "Effects of dietary supplementation with organic acids and zinc bacitracin on heal microflora, $\mathrm{pH}$ and performance in broilers," Turkish Journal of Veterinary and Animal Sciences, vol. 23, no. 5, pp. 451-455, 1999.

[18] R. M. Engberg, M. S. Hedemann, T. D. Leser, and B. B. Jensen, "Effect of zinc bacitracin and salinomycin on intestinal microflora and performance of broilers," Poultry Science, vol. 79, no. 9, pp. 1311-1319, 2000.

[19] M. Gunal, G. Yayli, O. Kaya, N. Karahan, and O. Sulak, "The effects of antibiotic growth promoter, probiotic or organic acid supplementation on performance, intestinal microflora and tissue of broilers," International Journal of Poultry Science, vol. 5, no. 2, pp. 149-155, 2006.

[20] J. Decuypere, H. K. Henderickx, and I. Vervaeke, "Influence of nutritional doses of virginiamycin and spiramycin on the quantitative and topographical composition of the gastrointestinal flora of artificially reared piglets," Zentralblatt für Bakteriologie, Parasitenkunde, Infektionskrankheiten und Hygiene. Erste Abteilung Originale. Reihe A: Medizinische Mikrobiologie und Parasitologie, vol. 223, no. 2, pp. 348-355, 1973.

[21] G. L. Bradley, T. F. Savage, and K. I. Timm, "The effects of supplementing diets with Saccharomyces cerevisiae var. boulardii on male poultry performance and ileal morphology," Poultry Science, vol. 73, pp. 1766-1770, 1994.

[22] E. R. L. Pelicano, P. A. Souza, H. B. A. Souza, et al., "Intestinal mucosa development in broiler chickens fed natural growth promoters," Revista Brasileira de Ciência Avícola, vol. 7, pp. 221-229, 2005.

[23] T. F. Savage, P. F. Cotter, and E. I. Zakrzewska, "The effect of feeding mannanoligosaccharide on immunoglobulins, plasma IgG and bile IgA of Wrolstad MW male Turkey," Poultry Science, vol. 75, supplement 1, p. 143, 1996. 
[24] S. Y. Radecki and M. T. Yakoyama, "Intestinal bacteria and their influence on Swine Nutrition," in Swine Nutrition, E. R. Miller, E. U. Daune, and A. J. Lewis, Eds., pp. 439-447, Butterworth-Heinemann, Boston, Mass, USA, 1991.

[25] K. R. Cera, D. C. Mahan, R. F. Cross, G. A. Reinhart, and R. E. Whitmoyer, "Effect of age, weaning and postweaning diet on small intestinal growth and jejunal morphology in young swine," Journal of Animal Science, vol. 66, no. 2, pp. 574-584, 1988.

[26] K. E. Yamauchi and Y. Isshiki, "Scanning electron microscopic observations on the intestinal villi in growing White Leghorn and broiler chickens from 1 to 30 days of age," British Poultry Science, vol. 32, no. 1, pp. 67-78, 1991. 

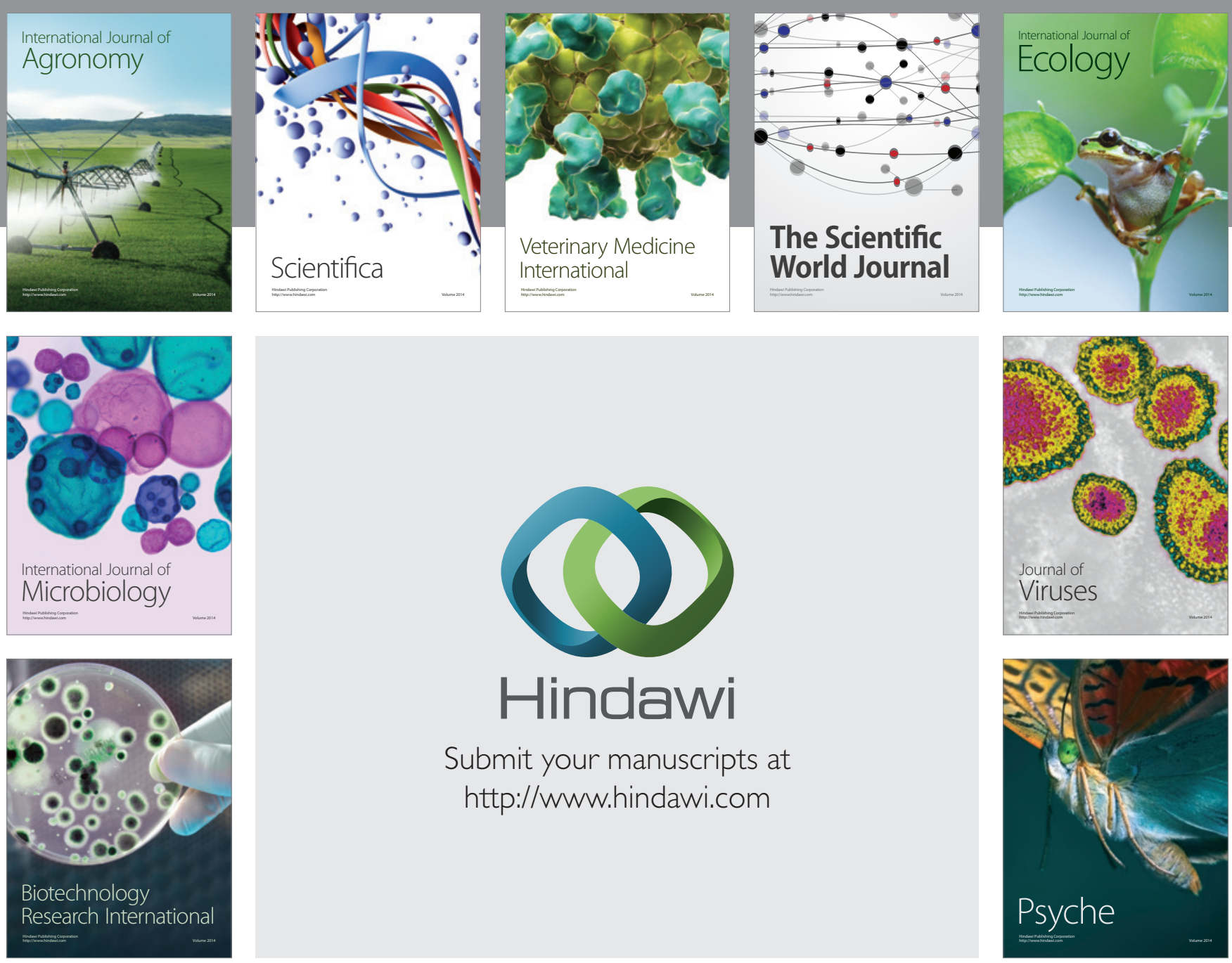

Submit your manuscripts at

http://www.hindawi.com
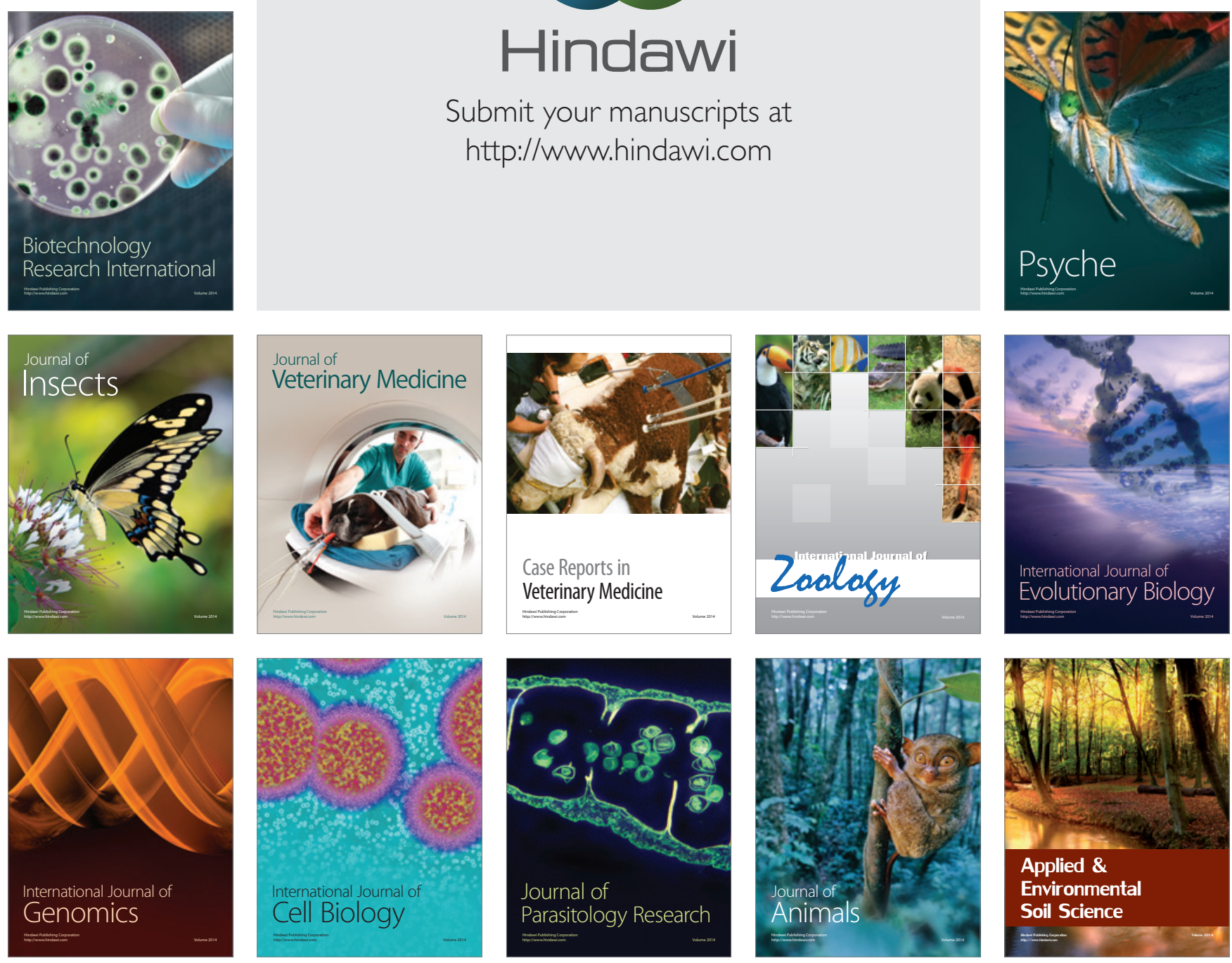